\title{
AKTUALNY STAN ROZWOJU HOSTELI NA TERENIE LUBLINA ${ }^{1}$
}

\begin{abstract}
Abstrakt: Artykuł jest próbą przedstawienia poziomu rozwoju hosteli na terenie Lublina na tle wielkości bazy hostelowej w Polsce. Źródłem danych wykorzystanych w pracy jest Główny Urząd Statystyczny. W pracy dokonano charakterystyki lokalizacji obiektów na terenie Lublina, ich oferty oraz przedstawiono ocenę gości na podstawie wybranych portali rezerwacyjnych. Słowa kluczowe: baza noclegowa, usługa hotelarska, hostel, Lublin.
\end{abstract}

\section{THE CURRENT STATE OF HOSTELS IN LUBLIN}

Abstract: The aim of the article is to present the role of hostels in the accommodation services market, with a particular emphasis on the city of Lublin and in contrast Poland. The source of data is the Central Statistical Office. The work based on a sample of 7 hostels includes their location, offer and rating by guests on selected booking portals to establish the service quality characters.

Keywords: Accommodation, hotel services, hostel, Lublin.

\section{WPROWADZENIE}

Lublin jest ważnym miastem z punktu widzenia historii Polski. W 2017 r. miasto świętował jubileusz 700-lecia lokacji na prawie magdeburskim. Już od lat 80 . XX w. Lublin postrzegany jest jako znaczący ośrodek krajoznawczej turystyki krajowej, będąc obok takich miast, jak Warszawa, Kraków czy Wrocław, wyróżnianym w Polsce jako wielkie centrum krajoznawcze (ŚWIECA 2009). Jako historycznie ukształtowane miasto wielokulturowe ma bardzo duży potencjał rozwoju turystyki.

Centralne położenie Lublina na obszarze między Wisłą i Bugiem zdecydowało o korzystnych naturalnych warunkach rozwoju miasta i jego dominującej pozycji gospodarczej $w$ regionie. Zamieszkiwany przez nieco ponad 340 tys. mieszkańców, jest dziewiątym pod względem zaludnienia miastem w Polsce (GUS... 2016). Aktualnie pełni funkcję stolicy województwa lubelskiego będąc historycznym i kulturalnym centrum środkowowschodniej części Polski.

Lublin jest także regionalnym węzłem turystycznym $\mathrm{z}$ dużym zapleczem noclegowym i bazą towarzyszącą; stanowi regionalny, krajowy i międzynarodowy węzeł komunikacji drogowej i kolejowej. Przez miasto przebiegają trzy drogi krajowe o znaczeniu międzynarodowym. Transport powietrzny umożliwia Port Lotniczy Lublin SA w Świdniku. Według danych GUS w Lublinie zdecydowanie najsilniej reprezento- waną grupą obiektów noclegowych są obiekty hotelowe, jednak ostatnio na znaczeniu zyskują hostele.

Jak pokazuje literatura przedmiotu (GRUSZKA, ILNICKI, KRAJEWSKA-SMARDZ 2015, BROCHADO, RITA, GAMEIRO 2015, CRÓ, MARTINS 2017a) hostel stanowi obecnie stosunkowo szybko rozwijającą się alternatywną formą noclegu w stosunku do klasycznych hoteli, zwłaszcza że niektóre z nich oferują swoim gościom usługi bardzo zbliżone poziomem do usług hotelowych, ale za znacznie niższą cenę. Stale powiększająca się baza hosteli w Polsce stanowi dynamicznie rosnący nowy poligon badawczy (m.in. CRÓ, MARTINS 2017a, b).

Celem artykułu jest charakterystyka aktualnego stanu rozwoju hosteli na terenie Lublina.

\section{MATERIAŁ I METODY}

Metodami zastosowanymi w pracy były analizy danych statystycznych oraz opinii gości zawartych na wybranych portalach rezerwacyjnych. Ponadto wykorzystano analizę materiałów uzyskanych w wyniku przeprowadzonej kwerendy i wywiadów bezpośrednich z właścicielami obiektów noclegowych. Zakres przestrzenny obejmował obszar Lublina, natomiast zakres czasowy to lata 2009-2016². 


\section{MIEJSCE HOSTELI W BAZIE NOCLEGOWEJ POLSKI}

W Polsce dla celów statystycznych obowiązuje klasyfikacja obiektów noclegowych. Wyodrębnia się następujące ich rodzaje: hotel, motel, pensjonat, inny obiekt hotelowy, dom wycieczkowy, schronisko, schronisko młodzieżowe, szkolne schronisko młodzieżowe, ośrodek wczasowy, ośrodek kolonijny, ośrodek szkoleniowo-wypoczynkowy, dom pracy twórczej, zespół domków turystycznych, kemping, pole biwakowe, hostel, zakład uzdrowiskowy, pokój gościnny (kwatera prywatna), kwatera agroturystyczna, pozostałe obiekty niesklasyfikowane (Turystyka w 2014). Do roku 2004 do grupy pozostałych obiektów niesklasyfikowanych zaliczano również obiekty, które nie spełniały wymogów kategoryzacyjnych dla poszczególnych rodzajów obiektów, a do 2008 r. również hostele.

Według definicji GUS hostele to obiekty noclegowe o standardzie różniącym się od obiektów hotelowych głównie liczbą miejsc w pokojach, wykorzystywaniem łóżek piętrowych i współdzieleniem części wyposażenia oraz pomieszczeń przeznaczonych dla gości (np. wspólna kuchnia/łazienka) (http:/ / stat.gov. $\mathrm{pl} /$ metainformacje/).

Rozwój turystyki w Polsce w ostatnich latach spowodował dynamiczny wzrost obiektów noclegowych w kraju. Analizując wielkość bazy noclegowej Polski w latach 2009-2014 można stwierdzić, że wzrost liczby obiektów noclegowych jest wciąż dynamiczny (tab. 1).
W roku 2014 na terenie Polski funkcjonowało 7251 obiektów zbiorowego zakwaterowania; dla porównania w 2009 r. było ich 6992. Największy wzrost przypada na hotele (38\%), zakłady uzdrowiskowe (25\%), zespoły domków turystycznych $(24 \%)$, pensjonaty $(22 \%)$, hostele $(500 \%)$, tym samym są one najbardziej dynamicznie rozwijającym się rodzajem obiektów zakwaterowania zbiorowego (tab. 1).

W strukturze bazy noclegowej Polski na 2014 r. dominują hotele (31\% ogółu obiektów noclegowych), ośrodki wczasowe (14\%), ośrodki szkoleniowo-wypoczynkowe $5,8 \%$ ) i zespoły domków turystycznych (5,6\%); hostele stanowią 1,6\%.

Według Głównego Urzędu Statystycznego w roku 2014 w Polsce funkcjonowało 114 hosteli, oferujących blisko 8 tys. miejsc noclegowych. W roku 2014 z usług hosteli skorzystało 501210 osób, udzielono 1135794 noclegów. Warto także dodać, że według GUS hostele charakteryzują się jednym $\mathrm{z}$ najwyższych wskaźników wykorzystania miejsc noclegowych, wynoszącym w 2014 r. 45,6\% (wskaźnik wykorzystania miejsc noclegowych $\mathrm{w}$ hotelach $\mathrm{w}$ tym samym roku stanowił $37 \%)$. Hostele w Polsce, podobnie jak w innych krajach Europy, zlokalizowane są przede wszystkim w dużych miastach, będących głównymi celami podróży turystycznych (tab. 2).

W roku 2014 liderem pod względem liczby hosteli wśród polskich miast był Kraków - 35 hosteli (31\% z ogólnej liczby wszystkich hosteli w Polsce) - oferujący łącznie 2702 miejsc noclegowych. W Poznaniu znajdowało się 11 hosteli (udział 10\%) z 448 miejscami

Tab. 1. Baza noclegowa Polski w latach 2009-2014

\begin{tabular}{|c|c|c|c|c|c|c|c|}
\hline Rodzaj obiektu & 2009 r. & $2010 \mathrm{r}$. & 2011 r. & 2012 r. & 2013 r. & 2014 r. & \begin{tabular}{|c|} 
Zmiana \\
2009-2014 \\
$(\%)$
\end{tabular} \\
\hline Hotel & 1634 & 1796 & 1883 & 2014 & 2107 & 2250 & +38 \\
\hline Motel & 119 & 123 & 123 & 116 & 116 & 110 & -7 \\
\hline Pensjonat & 274 & 293 & 289 & 311 & 307 & 337 & +22 \\
\hline Inne obiekty hotelowe & 809 & 1011 & 990 & 973 & 955 & 949 & +17 \\
\hline Dom wycieczkowy & 60 & 52 & 54 & 53 & 48 & 47 & -22 \\
\hline Schronisko & 62 & 60 & 65 & 61 & 60 & 59 & -5 \\
\hline Schronisko młodzieżowe & 52 & 52 & 46 & 44 & 45 & 45 & -13 \\
\hline Szkolne schronisko młodzieżowe & 290 & 294 & 281 & 282 & 274 & 267 & -8 \\
\hline Ośrodek wczasowy & 1199 & 1154 & 1080 & 1079 & 1047 & 1017 & -15 \\
\hline Ośrodek kolonijny & 111 & 100 & 101 & 92 & 99 & 93 & -16 \\
\hline Ośrodek szkoleniowo-wypoczynkowy & 464 & 494 & 465 & 450 & 432 & 420 & -9 \\
\hline Hostel & 19 & 71 & 84 & 108 & 110 & 114 & +500 \\
\hline Dom pracy twórczej & 39 & 37 & 35 & 37 & 34 & 35 & -10 \\
\hline Zespół domków turystycznych & 330 & 365 & 356 & 388 & 394 & 409 & +24 \\
\hline Kemping & 125 & 121 & 135 & 131 & 129 & 125 & - \\
\hline Pole biwakowe & 216 & 193 & 188 & 192 & 187 & 181 & -16 \\
\hline Zakład uzdrowiskowy & 158 & 158 & 158 & 190 & 198 & 197 & +25 \\
\hline Pozostałe obiekty niesklasyfikowane & 1031 & 832 & 706 & 656 & 610 & 596 & -42 \\
\hline Ogółem & 6992 & 7102 & 6574 & 7177 & 7152 & 7251 & +41 \\
\hline
\end{tabular}

Źródło: opracowanie własne na podstawie danych z https:/ / bdl.stat.gov.pl. 
WzGT 1(8) 2017

Tab. 2. Hostele w największych miastach Polski w latach 2009-2014

\begin{tabular}{|c|c|c|c|c|c|c|c|}
\hline Miasto & Rok & $\begin{array}{c}\text { Liczba } \\
\text { obiektów }\end{array}$ & $\begin{array}{l}\text { Liczba miejsc } \\
\text { noclegowych }\end{array}$ & $\begin{array}{l}\text { Korzystający } \\
\text { z noclegów }\end{array}$ & $\begin{array}{c}\text { Korzystający } \\
\text { z noclegów turyści } \\
\text { zagraniczni }\end{array}$ & $\begin{array}{c}\text { Udzielone } \\
\text { noclegi }\end{array}$ & $\begin{array}{l}\text { Średnia } \\
\text { długość } \\
\text { pobytu }\end{array}$ \\
\hline \multirow{6}{*}{ Warszawa } & 2009 & 1 & 36 & 1164 & 30 & 2310 & 1,98 \\
\hline & 2010 & 4 & 406 & 39925 & 20979 & 60063 & 1,50 \\
\hline & 2011 & 6 & 513 & 69841 & 31396 & 96851 & 1,39 \\
\hline & 2012 & 10 & 2037 & 16461 & 41755 & 377249 & 22,92 \\
\hline & 2013 & 10 & 1591 & 110096 & 43641 & 319591 & 2,90 \\
\hline & 2014 & 10 & 1282 & 128624 & 51626 & 295185 & 2,29 \\
\hline \multirow{6}{*}{ Kraków } & 2009 & 6 & 239 & 13881 & 8589 & 30089 & 2,17 \\
\hline & 2010 & 26 & 1298 & 99544 & 42204 & 201152 & 2,02 \\
\hline & 2011 & 30 & 1576 & 108469 & 49664 & 210205 & 1,94 \\
\hline & 2012 & 35 & 1746 & 129571 & 69718 & 257194 & 1,98 \\
\hline & 2013 & 37 & 2589 & 131950 & 67906 & 272752 & 2,07 \\
\hline & 2014 & 35 & 2702 & 149537 & 71243 & 307449 & 2,06 \\
\hline \multirow{6}{*}{ Łódź } & 2009 & 2 & 35 & 393 & 0 & 1528 & 3,89 \\
\hline & 2010 & 2 & 31 & 2991 & 67 & 4483 & 1,50 \\
\hline & 2011 & 4 & 143 & 8777 & 1282 & 24150 & 2,75 \\
\hline & 2012 & 11 & 644 & 23354 & 3005 & 64182 & 2,75 \\
\hline & 2013 & 10 & 541 & 23575 & 2823 & 61221 & 2,60 \\
\hline & 2014 & 8 & 504 & 27323 & 5082 & 61565 & 2,25 \\
\hline \multirow{6}{*}{ Wrocław } & 2009 & 1 & 34 & 700 & 0 & 1400 & 2,00 \\
\hline & 2010 & 7 & 331 & 23769 & 3572 & 44150 & 1,86 \\
\hline & 2011 & 10 & 523 & 42189 & 8697 & 72344 & 1,71 \\
\hline & 2012 & 9 & 599 & 40470 & 7910 & 76414 & 1,89 \\
\hline & 2013 & 10 & 655 & 49626 & 11650 & 94146 & 1,90 \\
\hline & 2014 & 10 & 871 & 59462 & 12560 & 113051 & 1,90 \\
\hline \multirow{6}{*}{ Poznań } & 2009 & 4 & 123 & 7997 & 2083 & 14126 & 1,77 \\
\hline & 2010 & 7 & 322 & 17035 & 4173 & 29397 & 1,73 \\
\hline & 2011 & 7 & 355 & 18326 & 3760 & 33583 & 1,83 \\
\hline & 2012 & 10 & 414 & 24776 & 6149 & 51681 & 2,09 \\
\hline & 2013 & 9 & 391 & 23980 & 2846 & 43349 & 1,81 \\
\hline & 2014 & 11 & 448 & 28309 & 2773 & 50805 & 1,79 \\
\hline \multirow{6}{*}{ Gdańsk } & 2009 & 0 & 0 & 0 & 0 & 0 & 0,00 \\
\hline & 2010 & 0 & 0 & 0 & 0 & 0 & 0,00 \\
\hline & 2011 & 2 & 79 & 1904 & 973 & 3716 & 1,95 \\
\hline & 2012 & 2 & 58 & 4886 & 2759 & 8624 & 1,77 \\
\hline & 2013 & 3 & 122 & 9586 & 4349 & 17591 & 1,84 \\
\hline & 2014 & 7 & 411 & 27091 & 9987 & 49785 & 1,84 \\
\hline \multirow{6}{*}{ Lublin } & 2009 & 0 & 0 & 0 & 0 & 0 & 0,00 \\
\hline & 2010 & 0 & 0 & 0 & 0 & 0 & 0,00 \\
\hline & 2011 & 0 & 0 & 0 & 0 & 0 & 0,00 \\
\hline & 2012 & 0 & 0 & 0 & 0 & 0 & 0,00 \\
\hline & 2013 & 1 & 34 & 147 & 0 & 413 & 2,81 \\
\hline & 2014 & 0 & 0 & 0 & 0 & 0 & 0,00 \\
\hline
\end{tabular}

Źródło: opracowanie własne na podstawie danych z https:/ / bdl.stat.gov.pl.

noclegowymi, w Warszawie i we Wrocławiu po 10 (9\%), odpowiednio z 1282 oraz 871 miejscami noclegowymi. Kolejne miejsca zajęły Łódź (8 obiektów), oferując 504 miejsca noclegowe, oraz Gdańsk - 7 hosteli i 411 miejsc noclegowych. Według danych GUS na terenie Lublina $\mathrm{w}$ analizowanym okresie zarejestrowany był tylko jeden hostel.

Z usług hosteli korzystają zarówno turyści z Polski, jak i z zagranicy. W 2014 r. najwięcej osób korzystających z noclegów zanotowano w Krakowie
(149 537 osób; $71243 \mathrm{z}$ nich to turyści zagraniczni) i Warszawie (128 624; 51626 osób z zagranicy). Te miasta są również głównymi celami przyjazdów turystów. Liczba udzielonych noclegów w Krakowie wynosiła 307 449, w Warszawie 295185.

Średnia długość pobytu to 2-3 dni, przy czym najdłuższe pobyty - około 23 dni - zanotowano w Warszawie w 2012 r. Sytuacja ta prawdopodobnie związana była $\mathrm{z}$ odbywającymi się $\mathrm{w}$ tym czasie w stolicy Mistrzostwami Europy w Piłce Nożnej Euro 2012. 


\section{ANALIZA HOSTELI W LUBLINIE}

Jak wynika z powyższej analizy, baza hostelowa Polski rozwijała się dość intensywnie w ciągu ostatnich lat. Przyrost hosteli w Polsce w latach 2009-2014 wyniósł średnio $500 \%$.

Warto zauważyć, że statystyczne dane odnośnie do bazy hostelowej Lublina nie są pełne. Porównanie oficjalnych danych GUS Banku Danych Lokalnych oraz danych $\mathrm{z}$ wykazu kart ewidencyjnych innych obiektów, w których świadczone są usługi hotelarskie Urzędu Miasta Lublina $\mathrm{z}$ portalami rezerwacyjnymi, takimi jak www.booking.com, www.trivago.pl, esky.pl wskazuje na to, że rzeczywisty rynek hosteli w Lublinie jest znacznie większy. Ta rozbieżność wynika ze specyfiki badania statystycznego w Polsce oraz swobody wyboru nazw stosowanych do obiektów niesklasyfikowanych. W przypadku obiektów niekategoryzowanych podział na grupy ma charakter umowny. Często możemy spotkać się z tym, że obiekty o podobnym standardzie i $\mathrm{z}$ podobnym zakresem usług używają różnych nazw rodzajowych.

Według najnowszych publikowanych danych GUS (rok 2014) baza hosteli Lublina nie jest rejestrowana w ogólnopolskiej statystyce. Z tego względu podjęto $\mathrm{w}$ pracy badania pierwotne.

Przeprowadzone studia terenowe wykazały, że wszystkie hostele Lublina zlokalizowane są w centrum miasta. Teren zabudowy staromiejskiej z obiektami historycznymi jest najbardziej atrakcyjnym miejscem dla lokalizacji hosteli. Większość z hosteli mieści się ponadto $\mathrm{w}$ zabytkowych kamienicach, co dodaje atrakcyjności pobytu w nich.

Badanie pierwotne pokazało, że w Lublinie pod koniec 2016 r. funkcjonowało sześć hosteli, oferujących łącznie swoim gościom 76 pokoi. Hostele Lublina dysponują ogółem 234 miejscami noclegowymi. Wszystkie hostele są dostępne dla turystów przez cały rok. Ich pojemność nie jest wyraźnie zróżnicowana, większość obiektów ma około 10 pokoi, jedynie hostel "Lublin" dysponuje sześcioma pokojami, a hostel "Cent" liczy ich najwięcej - 30. To samo dotyczy liczby miejsc noclegowych. Wszystkie hostele mają około 30 miejsc noclegowych, z wyjątkiem hostelu "Cent", który może pomieścić jednocześnie 80 osób (tab. 3).

Najstarszym (otworzonym w 2009 r.) hostelem w mieście jest „Lublin”. Zlokalizowany jest przy ulicy Lubartowskiej 60, w odległości pięciu minut spacerem od Zamku i Starego Miasta. Oferuje pokoje wieloosobowe (5-8-osobowe) oraz prywatne (1- lub 2-osobowe) ze wspólną łazienką. Następnie powstał hostel "Królewska”, który znajduje się przy ulicy Królewskiej $6 \mathrm{w}$ Lublinie. Ulokowany jest w zabytkowej kamienicy, oferuje pokoje 2-, 3-, 4- i 5-osobowe i z każdego $\mathrm{z}$ nich jest widok na deptak lub Stare Miasto.
Tab. 3. Wielkość bazy hostelowej Lublina

\begin{tabular}{|l|c|c|}
\hline Nazwa hostelu & $\begin{array}{c}\text { Liczba } \\
\text { pokoi }\end{array}$ & $\begin{array}{c}\text { Liczba miejsc } \\
\text { noclegowych }\end{array}$ \\
\hline "Lublin" & 6 & 30 \\
\hline "Królewska” & 9 & 30 \\
\hline "Folk" & 10 & 28 \\
\hline "Cent" & 30 & 80 \\
\hline "Orla" & 11 & 32 \\
\hline "LoLek" & 10 & 34 \\
\hline Razem & 76 & 234 \\
\hline
\end{tabular}

Źródło: opracowanie własne na podstawie badań terenowych

Po hostelu „Królewska” powstał hostel „Folk” - przy ulicy Krakowskie Przedmieście 23 (wejście od ulicy Zielonej). Oferuje on pokoje 1-, 2-, 3-, 4- i 6-osobowe, łóżka w pokojach wieloosobowych, pokój z łazienką oraz apartament. Nowością hostelu „Folk” jest apartament $\mathrm{z}$ wanną z hydromasażem.

Największym hostelem Lublina jest hostel „Cent”, a jego właścicielem jest sieć hotelowa Vanilla Group. Obiekt znajduje się w zabytkowej kamienicy przy ulicy Ewangelickiej 6, zaledwie kilka minut spacerem od lubelskiego deptaka, 10 minut od Starego Miasta, 15 minut od miasteczka akademickiego. Hostel "Cent" oferuje miejsca w komfortowo wyposażonych pokojach 2-, 3-, 4- i 5-osobowych. Wszystkie pokoje mają dostęp do aneksu kuchennego, wspólnego salonu z TV i książkami.

Hostel „Orla” jest zlokalizowany przy ulicy Orlej 6, w samym centrum miasta, w odległości $500 \mathrm{~m}$ od placu Litewskiego oraz 10 minut piechotą od Starego Miasta. W pobliżu znajduje się także wiele innych atrakcji Lublina, takich jak: Centrum Kultury, Centrum Handlowe „Plaza”, miasteczko akademickie, Ogród Saski, Krakowskie Przedmieście oraz liczne zabytki. Oferuje pokoje 2-, 4-osobowe oraz pojedyncze miejsca w pokojach wieloosobowych.

Hostel "LoLek" jest najnowszym obiektem tego typu w Lublinie. Położony jest przy Bernardyńskiej 9 w zabytkowej kamienicy. Od katedry lubelskiej, Starego Miasta oraz Krakowskiego Przedmieścia dzieli go zaledwie kilka kroków, mieści się w samym centrum miasta, ale $\mathrm{z}$ dala od jego zgiełku. W niewielkiej odległości od hostelu „LoLek” znajduje się fabryka Browaru „Perła”. Hostel oferuje pokoje 1-, 2-, 3-, 4- i 8-osobowe.

\section{OCENA WYBRANYCH HOSTELI W OPINII BOOKING.COM, ESKY.PL ORAZ TRIVAGO.PL}

Większość turystów korzysta z różnych serwisów rezerwacyjnych, które nie tylko dają możliwość dokonania rezerwacji miejsca noclegowego, ale również po- 
zwalają na zamówienie wszelkich innych dodatkowych usług. Po zakończeniu pobytu, goście mogą za pośrednictwem serwisu wyrazić swoją opinię na temat danego obiektu noclegowego, z którego korzystali. Można zatem uznać, że wystawione $\mathrm{w}$ ten sposób oceny oraz wyrażone opinie są prawdziwe i rzeczywiście pochodzą od osób, które osobiście odwiedziły dany obiekt.

Wybranymi z wielu takich serwisów rezerwacyjnych uwzględnionych $\mathrm{w}$ niniejszej pracy są booking. com, esky.pl oraz trivago.pl (tab. 4).

Jak wynika $\mathrm{z}$ przeprowadzonych analiz, najlepiej ocenionym obiektem wśród hosteli Lublina jest hostel "LoLek". Na wszystkich wskazanych serwisach rezerwacyjnych opinie o tym hostelu wyraziło 1341 gości. Wśród 775 opinii przedstawionych za pośrednictwem booking.com, hostel „Lolek” uzyskał miano „znakomity", ze średnią oceną 9,2 punkty na 10 możliwych. Bardzo wysoko oceniona została lokalizacja hostelu, czystość pomieszczeń oraz kwalifikacje personelu.

Wśród 537 opinii znalezionych na stronie trivago. pl goście również najwyżej ocenili lokalizację, higienę obiektu oraz usługi hostelu. Oceniający określili ten obiekt mianem „idealny” oraz przydzielili mu 89 punktów spośród 100 możliwych. Status „najlepszy wybór" uzyskał wśród gości korzystających z serwisu esky.pl hostel „LoLek”. Wśród 29 zamieszczonych na stronie recenzji lokalizacja hostelu oraz jego obsługa uzyskały najwyższą ocenę 5 punktów w skali od 1 do 5 , natomiast ocena ogólna obiektu wyniosła 4,5 punktu. Oceny hostelu „LoLek” przyznane przez użytkowników portali rezerwacyjnych zamieszczono w tab. 4 .

Tab. 4. Oceny przyznane hostelowi „LoLek” przez użytkowników portali rezerwacyjnych

\begin{tabular}{|l|c|l|c|l|c|}
\hline \multicolumn{2}{|c|}{$\begin{array}{c}\text { Booking.com } \\
(0-10 \text { pkt) } \\
N=775\end{array}$} & \multicolumn{2}{c|}{$\begin{array}{c}\text { Esky.pl } \\
(0-5 \text { pkt }) \\
N=29\end{array}$} & \multicolumn{2}{c|}{$\begin{array}{c}\text { Trivago.pl } \\
(0-100 \text { pkt }) \\
N=537\end{array}$} \\
\hline Czystość & 9,6 & Lokalizacja & 5,0 & Położenie & 93 \\
\hline Komfort & 8,8 & $\begin{array}{l}\text { Jakość } \\
\text { noclegu }\end{array}$ & 4,5 & Pokoje & 82 \\
\hline Lokalizacja & 9,5 & Pokoje & 4,5 & Usługi & 92 \\
\hline Udogodnienia & 8,9 & Obsługa & 5,0 & Czystość & 92 \\
\hline Personel & 9,4 & Wartość & 4,5 & Jakość a cena & 89 \\
\hline $\begin{array}{l}\text { Stosunek jakości } \\
\text { do ceny }\end{array}$ & 9,2 & Czystość & 4,5 & Komfort & 87 \\
\hline Bezpłatne WiFi & 9,2 & - & & Udogodnienia & 87 \\
\hline Średnia & 9,2 & Średnia & 4,5 & Średnia & 89 \\
\hline
\end{tabular}

Źródło: opracowanie własne.

Bardzo wysoko wśród hosteli Lublina został oceniony hostel "Orla”, przy liczbie 1690 opinii (tab. 5). Goście, którzy rezerwowali nocleg przez serwis booking.com określili hostel „Orla" mianem „fantastyczny” i ocenili go na 8,9 punktów z 10 możliwych. Najlepsze opinie uzyskała dogodna lokalizacja, czystość obiektu oraz obsługa personelu.

Na podstawie 718 opinii pozostawionych na portalu trivago.pl hostel "Orla" otrzymał 85 punktów na 100 możliwych i został określony mianem „idealny”. Lokalizacja oraz czystość tego obiektu to cechy najwyżej ocenione przez respondentów. Status „świetnie oceniany" uzyskał wśród oceniających na stronie esky. pl hostel „Orla”. Stosownie do 25 wystawionych recenzji, większość ocenianych cech hostelu otrzymało średnią notę 4,5 punktu, natomiast średnia ocena ogólna wyniosła 4 punkty w skali 5-stopniowej.

Tab. 5. Oceny przyznane hostelowi „Orla” przez użytkowników portali rezerwacyjnych

\begin{tabular}{|l|c|l|l|l|l|}
\hline \multicolumn{2}{|c|}{$\begin{array}{c}\text { Booking.com } \\
(0-10 \text { pkt }) \\
N=946\end{array}$} & \multicolumn{2}{c|}{$\begin{array}{c}\text { Esky.pl } \\
(0-5 \text { pkt }) \\
N=25\end{array}$} & \multicolumn{2}{c|}{$\begin{array}{c}\text { Trivago.pl } \\
(0-100 \text { pkt }) \\
N=718\end{array}$} \\
\hline Czystość & 9,1 & Lokalizacja & 4,5 & Położenie & 89 \\
\hline Komfort & 8,5 & $\begin{array}{l}\text { Jakość } \\
\text { noclegu }\end{array}$ & 3,5 & Pokoje & 79 \\
\hline Lokalizacja & 9,1 & Pokoje & 4,5 & Usługi & 87 \\
\hline Udogodnienia & 8,5 & Obsługa & 4,0 & Czystość & 89 \\
\hline Personel & 9,1 & Wartość & 4,5 & Jakość a cena & 86 \\
\hline $\begin{array}{l}\text { Stosunek jakości } \\
\text { do ceny }\end{array}$ & 9,0 & Czystość & 4,5 & Komfort & 84 \\
\hline Bezpłatne WiFi & 8,9 & - & & Udogodnienia & 84 \\
\hline Średnia & 8,9 & Średnia & 4,0 & Srednia & 85 \\
\hline
\end{tabular}

Źródło: opracowanie własne.

Tab. 6. Oceny przyznane hostelowi „Cent" przez użytkowników portali rezerwacyjnych

\begin{tabular}{|l|c|l|r|l|l|}
\hline \multicolumn{2}{|c|}{$\begin{array}{c}\text { Booking.com } \\
(0-10 \text { pkt }) \\
N=334\end{array}$} & \multicolumn{2}{c|}{$\begin{array}{c}\text { Esky.pl } \\
(0-5 \text { pkt })\end{array}$} & \multicolumn{2}{c|}{$\begin{array}{c}\text { Trivago.pl } \\
(0-100 \text { pkt }) \\
N=55\end{array}$} \\
\hline Czystość & 9,2 & Lokalizacja & 5,0 & Położenie & 91 \\
\hline Komfort & 8,4 & $\begin{array}{l}\text { Jakość } \\
\text { noclegu }\end{array}$ & 4,5 & Pokoje & 83 \\
\hline Lokalizacja & 9,4 & Pokoje & 4,5 & Usługi & 92 \\
\hline Udogodnienia & 8,2 & Obsługa & 4,5 & Czystość & 90 \\
\hline Personel & 9,1 & Wartość & 4,5 & Jakość a cena & 86 \\
\hline $\begin{array}{l}\text { Stosunek jakości } \\
\text { do ceny }\end{array}$ & 8,8 & Czystość & 4,5 & Komfort & 83 \\
\hline Bezpłatne WiFi & 8,4 & - & & Udogodnienia & 81 \\
\hline Średnia & 8,8 & Średnia & 4,5 & Średnia & 86 \\
\hline
\end{tabular}

Źródło: opracowanie własne.

Osoby oceniające hostel "Cent" poprzez portal booking.com określiły go jako „fantastyczny” (334 opinie) i uzyskał on ocenę 8,8 punktów na 10 możliwych. Najwyższe noty zdobyła lokalizacja obiektu (9,4 pkt), czystość pomieszczeń oraz personel.

W 352 opiniach zamieszczonych w serwisie trivago. pl hostel "Cent" również określono mianem „idealny” oraz wyróżniono 86 punktami spośród 100 możli- 
wych. Goście wyrażali swoje zadowolenie głównie z dobrej lokalizacji obiektu, czystości pokoi i łazienek oraz oferowanych usług. Mianem „najlepszy wybór!” określiło ten hostel 55 gości korzystających z serwisu esky.pl, wystawiając mu jednocześnie średnią ocenę w wysokości 4,5 punktu.

Podobne oceny wystawione przez gości otrzymały dwa kolejne obiekty - hostel „Królewska” oraz hostel „Folk”. Oceny przyznane tym obiektom przez użytkowników portali rezerwacyjnych zamieszczono w tab. 7 oraz tab. 8. Zarówno hostel „Królewska”, jak i „Folk” uzyskały miano „fantastyczny” z oceną 8,6 punktu w 10-stopniowej skali na stronie booking.com. Najwyżej ocenione zostały takie cechy wymienionych obiektów, jak bardzo dobra lokalizacja hostelu, czystość pomieszczeń oraz personel.

Tab. 7. Oceny przyznane hostelowi „Królewska” przez użytkowników portali rezerwacyjnych

\begin{tabular}{|c|c|c|c|c|c|}
\hline \multicolumn{2}{|l|}{$\begin{array}{c}\text { Booking.com } \\
\text { (0-10 pkt) } \\
N=601\end{array}$} & \multicolumn{2}{|l|}{$\begin{array}{c}\text { Esky.pl } \\
(0-5 \text { pkt }) \\
N=37\end{array}$} & \multicolumn{2}{|l|}{$\begin{array}{c}\text { Trivago.pl } \\
\text { (0-100 pkt) } \\
N=605\end{array}$} \\
\hline Czystość & 8,6 & Lokalizacja & 5,0 & Położenie & 92 \\
\hline Komfort & 8,1 & Jakość noclegu & 3,5 & Pokoje & 79 \\
\hline Lokalizacja & 9,5 & Pokoje & 3,5 & Usługi & 87 \\
\hline Udogodnienia & 8,0 & Obsługa & 4,0 & Czystość & 85 \\
\hline Personel & 9,0 & Wartość & 4,0 & Jakość a cena & 82 \\
\hline $\begin{array}{l}\text { Stosunek jakości } \\
\text { do ceny }\end{array}$ & 8,6 & Czystość & 4,5 & Komfort & 81 \\
\hline Bezpłatne WiFi & 8,7 & - & & Udogodnienia & 80 \\
\hline Średnia & 8,6 & Średnia & 3,5 & Średnia & 84 \\
\hline
\end{tabular}

Źródło: opracowanie własne.

Tab. 8. Oceny przyznane hostelowi „Folk” przez użytkowników portali rezerwacyjnych

\begin{tabular}{|c|c|c|c|c|c|}
\hline \multicolumn{2}{|l|}{$\begin{array}{c}\text { Booking.com } \\
\text { (0-10 pkt) } \\
N=437\end{array}$} & \multicolumn{2}{|l|}{$\begin{array}{c}\text { Esky.pl } \\
(0-5 \text { pkt) } \\
N=31\end{array}$} & \multicolumn{2}{|l|}{$\begin{array}{c}\text { Trivago.pl } \\
(0-100 \text { pkt }) \\
N=513\end{array}$} \\
\hline Czystość & 8,7 & Lokalizacja & 4,5 & Położenie & 89 \\
\hline Komfort & 8,1 & Jakość noclegu & 3,5 & Pokoje & 79 \\
\hline Lokalizacja & 9,3 & Pokoje & 4,5 & Usługi & 86 \\
\hline Udogodnienia & 8,2 & Obsługa & 4,5 & Czystość & 85 \\
\hline Personel & 8,9 & Wartość & 4,0 & Jakość a cena & 81 \\
\hline $\begin{array}{l}\text { Stosunek jakości } \\
\text { do ceny }\end{array}$ & 8,5 & Czystość & 4,5 & Komfort & 78 \\
\hline Bezpłatne WiFi & 9,1 & & & Udogodnienia & 79 \\
\hline Średnia & 8,6 & Średnia & 4,0 & Średnia & 85 \\
\hline
\end{tabular}

Źródło: opracowanie własne.

Z opinii zamieszczonych za pośrednictwem serwisu trivago.pl wynika, że respondenci również dość wysoko ocenili lokalizację obiektów, czystość oraz usługi oferowane przez hostele. Hostel „Królewska” zyskał wśród gości opinię "bardzo dobry” oraz ocenę 84 punkty na 100 możliwych. Mianem „idealny” natomiast goście określili hostel „Folk”, który otrzmał jednocześnie średnią ocenę 85 punktów. Na portalu esky.pl dla hostelu „Królewska” pozostawiono 37 opinii $\mathrm{z}$ jednoczesną ogólną oceną tego miejsca noclegowego wynoszącą 3,5 punktu. Hostel „Folk” w tym samym serwisie uzyskał 31 opinii ze średnią oceną obiektu 4 punktów w 5-stopniowej skali.

Słabiej ocenionym obiektem wśród hosteli Lublina został hostel "Lublin”. 269 opinii wyrażonych na booking.com określiło jego status jako „dobry”, ze średnią oceną 7 punktów na 10 możliwych. Lokalizacja hostelu jest oceniana zdecydowanie gorzej $\mathrm{w}$ porównaniu $\mathrm{z}$ położeniem innych obiektów tego typu na terenie Lublina

Hostel „Lublin” oceniło za pośrednictwem serwisu trivago.pl 425 gości i uzyskał on 70 punktów ze 100 możliwych - ze względu na niską ocenę lokalizacji, czystości obiektu oraz jakości oferowanych usług. Z 28 ocen wystawionych dla tego obiektu na portalu esky.pl wynika, że średnia nota to 2,5 punktu ze względu na niską ocenę jakości noclegu oraz wyposażenie pokoi. Ogólna średnia ocena hostelu "Lublin” na tej stronie internetowej wyniosła 3 punkty w skali $1-5$.

Tab. 9. Oceny przyznane hostelowi „Lublin” przez użytkowników portali rezerwacyjnych

\begin{tabular}{|l|r|l|l|l|l|}
\hline \multicolumn{2}{|c|}{$\begin{array}{c}\text { Booking.com } \\
\text { (0-10 pkt) } \\
N=269\end{array}$} & \multicolumn{2}{c|}{$\begin{array}{c}\text { Esky.pl } \\
\text { (0-5 pkt) }\end{array}=28$} & \multicolumn{2}{c|}{$\begin{array}{c}\text { Trivago.pl } \\
(0-100 \text { pkt })\end{array}$} \\
\hline Czystość & 6,9 & Lokalizacja & 3,0 & Położenie & 77 \\
\hline Komfort & 6,3 & Jakość noclegu & 2,5 & Pokoje & 71 \\
\hline Lokalizacja & 7,6 & Pokoje & 2,5 & Usługi & 80 \\
\hline Udogodnienia & 6,3 & Obsługa & 3,5 & Czystość & 76 \\
\hline Personel & 7,7 & Wartość & 3,0 & Jakość a cena & 76 \\
\hline $\begin{array}{l}\text { Stosunek } \\
\text { jakości do ceny }\end{array}$ & 7,0 & Czystość & 3,0 & Komfort & 70 \\
\hline Bezpłatne WiFi & 8,1 & - & & Udogodnienia & 71 \\
\hline Średnia & 7,0 & Średnia & 3,0 & Średnia & 70 \\
\hline
\end{tabular}

Źródło: opracowanie własne.

Podsumowując ogólnie wyrażone przez turystów zdanie nt. hosteli w Lublinie można stwierdzić, że największym atutem przy wyborze hostelu przez gości okazała się dogodna jego lokalizacja. W swoich opiniach najwięcej osób wspominało również o czystości pokoi oraz łazienek. Duże znaczenie dla turystów miały także kwalifikacje i uprzejmość personelu.

\section{WNIOSKI}

Hostele są stosunkowo nowym obiektem zbiorowego zakwaterowania, ale $\mathrm{z}$ roku na rok cieszą się coraz większą popularnością zarówno wśród zorganizo- 
wanych grup turystycznych, jak i pojedynczych osób odwiedzających daną miejscowość, będąc tym samym alternatywą i konkurencją dla dużych sieci hotelowych.

W porównaniu do wspomnianych $\mathrm{w}$ artykule innych dużych miast w Polsce Lublin nie posiada zbyt dużej liczby hosteli, ale rynek usług turystycznych stale rozwija się w mieście. Większość hosteli znajdujących się w Lublinie w dalszym ciągu może zaproponować gościom jedynie pokoje o niskim standardzie - podstawowe wyposażenie łazienek oraz ograniczony zakres usług. Większość obiektów zlokalizowanych jest w ścisłym centrum miasta.

Analiza jakości usług oferowanych przez lubelskie hostele, dokonana na podstawie ocen wystawionych przez ich gości na portalach rezerwacyjnych wykazała stosunkowo wysoki ich poziom. Najlepiej oceniono ich położenie $\mathrm{w}$ mieście, poziom usług i przychylne nastawienie personelu.

\section{PRZYPISY}

1 Artykuł powstał na podstawie pracy licencjackiej Lilii Myroshnichenko pt. Aktualny stan rozwoju hosteli na terenie Lublina obronionej na Wydziale Nauk o Ziemi i Gospodarki Przestrzennej UMCS w $2017 \mathrm{r}$.

2 Statystyki obejmują okres do 2014 r., natomiast pozostałe lata to badania pierwotne autorów.

\section{BIBLIOGRAFIA}

BROCHADO, A., RITA, P., GAMEIRO C., 2015, Exploring backpackers' perceptions of the hostel service quality, "International Journal of Contemporary Hospitality Management", 27(8), s. 18391855 .

CRÓ S., MARTINS A., 2017a, The importance of security for hostel price premiums: European empirical evidence, „Tourism Management", 60, s. 159-165.

CRÓ S., MARTINS A.M., 2017b, Hotel and hostel location in Lisbon: looking for their determinants, "Tourism Geographies," DOI: 10.1080/14616688.2017.1360386.

GRUSZKA I., ILNICKI D., KRAJEWSKA-SMARDZ A., 2015, Hostele jako nowy element infrastruktury noclegowej Wroctawia, "Rozprawy Naukowe AWF we Wrocławiu", 51, s. 66-75.

ŚWIECA A., 2009, Miasto Lublin jako przestrzeń turystyczna. Stare $i$ nowe struktury spoteczne $w$ Polsce, Wyd. UMCS, Lublin, s. 69-92.

Turystyka w 2014 roku, 2015, GUS, Warszawa.

http:// folkhostel.pl; 17.04.2017.

http:// hostelkrolewska.pl; 17.04.2017.

http://lolekhostel.pl; 17.04.2017.

http://stat.gov.pl; 19.01.2017.

http:/ / www.centhostel.pl; 17.04.2017.

http:/ / www.hostellublin.pl; 17.04.2017.

http:// www.hostelorla.pl; 17.04.2017.

https://bdl.stat.gov.pl; 19.01.2017.

https:// www.booking.com; 17.04.2017.

https://www.esky.pl; 1.05.2017.

https://www.trivago.pl; 1.05.2017. 
